Behçet 病に伴う腹部大動脈瘤および胃癌に対し 2 期的手術を施行した 1 例

関西医科大学付属洛西ニュータウン病院外科, 関西医科大学外科* 中本博之箕浦俊之小田道夫 今 村敦*

症例は51歳の男性. 30歳より Behçet 病にて加療中で, 平成15年 8 月.上部消化管内視鏡 検直にて肉眼型 2 型胃癌と診断された。さらにCT 検查にて最大径 $5 \mathrm{~cm}$ の腎動脈下腹 部大動脈瘤を認めたため 9 月26日腹部大動脈瘤に対し人下血管置換術を，10月10日胃癌 に対し幽門側胃切除を施行した。術後経過は概放良好で，胃癌の術後40日目に退院とな ったが, 約 1 年 1 カ月後多発性骨転移から DIC となり脳出血により死亡した。本症例は 血管 Behçet としては典型的である.しかし, Behçet 病と消化管覀性腫瘍との合併は極 めて稀で，本邦では本症例も含めて12例のみであった．今回の症例は 2 期的手術を選択 し良好な術後経過を得たが，今後は個々の症例に応じ， 1 期的手術か 2 期的手術かを厳 重に検討して決定すべきであると思われた。

索引用語：Behçet 病, 腹部大動脈瘤, 胃癌

緒言

Behçet 病は慢性僄延性経過をたどる全身性炎症性 疾患であり，口腔粘膜の再発性アフタ性潰瘍，外陰部 潰瘍，眼病変抢よび皮豦病変を主訴とするが，この他， 関節, 血管系, 腸管, 中枢神経など全身に病変を生じ る.しかし, Behçet 病と消化管悪性腫瘍の合併は極め て稀である.今回，われわれは腹部大動脈瘤を伴う血 管 Behçetに胃癌を合併した症例を経験したので報告 する.

\section{症例}

患者：51歳，男性.

主訴：特になし。

既往歴：30歳より Behçet 病にて加療。32歳より Behçet 病によるブドウ膜炎にて全盲となる。

家族歴：特記すべきことなし.

現病歴：平成15年 5 月 2 日に受けた青集団検診にて 異常を指摘され，8月21日上部消化管内視鏡検查を行 ったところ, 胃体中部から前庭部にいたる巨大な隆起 性病変を認めた，同部の生検から中分化型管状腺癌が 検出されたため，肉眼型 2 型胃癌と診断し 9 月 8 日手

2005 年 8 月 23 日受付 2005 年12月 2 日採用

〈所属施設住所〉

干610-1142 京都市西京区大枝東新林町 3-6
術目的にて入院となった。

本症例は Behçet 病の主症状の内, 口腔粘膜の再発 性アフタ性潰瘍, 眼症状 (網膜ぶどう膜炎), 外陰部潰 瘍の 3 症状が出現しており, 平成15年 4 月より当院内 科においてコルヒチン 1 日 1 錠投与にて経過観察され ていた.

入院時現症: 身長 $175 \mathrm{~cm}$, 体重 $60 \mathrm{~kg}$, 体温 $37.0^{\circ} \mathrm{C}$, 血圧 $128 / 80 \mathrm{mmHg}$, 脈拍 105 回/分, 舌および陰軎に潰 湟を認めた。

入院時検查所見：白血球数 $12,400 / \mathrm{ul}$, CRP $5.6 \mathrm{mg} /$ dl と炎症反応がみられ, 腫瘍アーカーCA19-9 が287 $\mathrm{U} / \mathrm{ml}$ と著明な上昇を呈した。

上部消化管造影検查：立位充満像および二重造影に て，胃体中部から前庭部におよぶ巨大な隆起性病変を 認めた（図 1)。

上部消化管内視鏡検查：胃体中部大彎側に易出血性 の肉眼型 2 型の巨大腫晹を認めた.

CT 検查：胃内腔に突出する隆起性病変，胃周囲リ ンパ節の腫脹および, 最大径 $5 \mathrm{~cm}$ の腎動脈下腹部大 動脈溜が発見された（図 2 )。

3D-CT 検査：腎動脈下腹部大動脈の 2 力所に, 襄状 の突出を認めた（図 3 ).

入院後, 腰部痛を訴え, CT 検査にて腹部大動脈瘾が 発見されたため, 破裂の危険を考え平成15年 9 月26日 


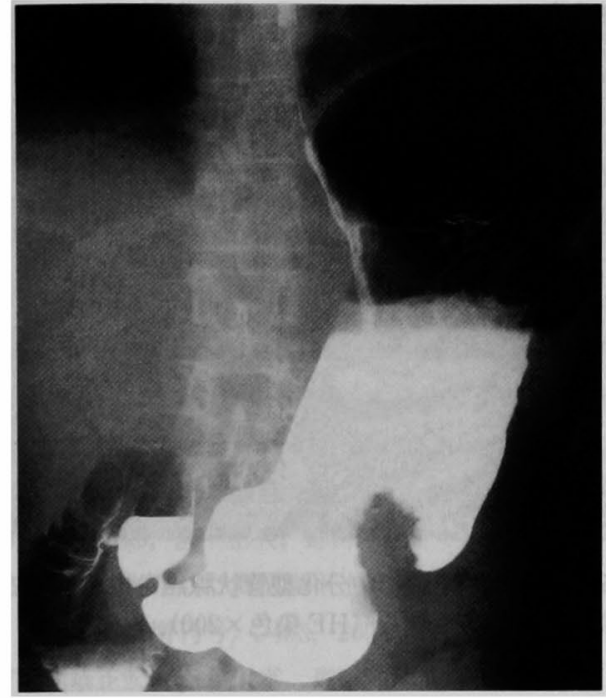

図 1 上部消化管造影検査：立位充満像では, 胃 体下部から前庭部にかけて巨大な隆起性病変 が認められる。

腹部大動脈瘤に対し人工血管置換術を行った後, 10月 10日胃癌に対し幽門側胃切除を行った.

手術所見：腹部大動脈瘤に対する手術では，後腹膜 到達法にて腹部大動脈に到達, Y graft（Woven Double Velour Vascular Graft D：14×7 mm）中枢側は 腎動脈直下にて，脚部をそれぞれ総腸骨動脈に端々吻 合した後, 中枢側の吻合部を人工血管残布で被覆した。 胃癌に対する手術では, 上腹部正中切開にて開腹, 腹 水は認めず腫湯の槳膜浸潤はなかったが，胃周囲のリ ンパ節が腫大しており，特にリンパ節 No. 5 は鵎卵大 まで腫大していた，腸管 Behçet を思わせる所見はな かった。また，人工血管置換部分に異常は認めなかっ た. H0P0T2N2 (Stage IIIA) と診断し幽門側胃切除, 2 群リンパ節郭清術を施行した。切除標本にて $8 \times 6.5$ $\mathrm{cm}$ の巨大な隆起性病変を認めた（図 4 ).

病理所見：胃体中部から前庭部におよぶ病変は肉眼 型 2 型の進行癌で, 組織学的には tub2 por, INF $\gamma$, ss, $\mathrm{PM}(-), \mathrm{DM}(-), \mathrm{pN} 1(12 / 14), \mathrm{pN} 2(5 / 13) \tau$ あり， stage IIIA であった (図 5 )。動脈瘤の瘤壁は, 外弾性板での中膜の解離があり, 解離面でのムコイド 様物質の沈着と中膜の弾性瀻維の減少およびプラズマ 球，リンパ球の炎症性細胞浸潤がみられた。

術後経過は概ね良好で，腫瘍マーカーCA19-9 も35 $\mathrm{U} / \mathrm{ml}$ まで低下し胃癌の術後40日目に退院となった。 しかし, 約10力月後に多発性骨転移をきたし, 約 1 年
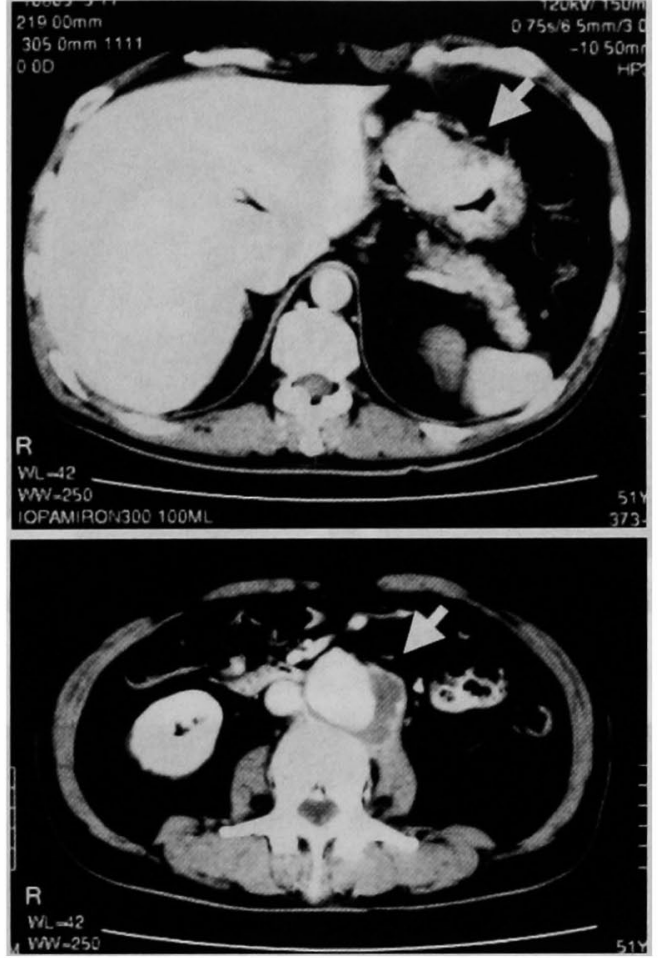

図 2 腹部 CT 検査：A）胃内腔に突出する巨大な隆 起性病変を諗める (矢印). B) 最大径約 $5 \mathrm{~cm}$ の腹 部大動脈瘤を認める (矢印).

$\frac{\mathrm{A}}{\mathrm{B}}$

1 カ月後 DIC となり脳出血により永眠された。

考察

Behçet 病は1937年トルコの皮虑科医 Behçet が再 発性の口腔内アフタ性潰瘍, 外陰部有痛性潰瘍, ぶど う膜炎を三主徵とする疾患を報告したことに始まる． 現在では口腔粘膜の再発性アフ夕性潰㰾, 皮虔症状, 眼症状, 外陰部潰瘍の 4 主症状を中心とする炎症症状 の再燃性, 遷延経過をとる原因不明の全身炎症性疾患 として諗知されている゙. 本邦においては, 本症を上記 4 主症状を示す完全型とそうでない不完全型に分類し ている。また，特殊病型として，腸管の潰瘍性病変を 示す腸管 Behçet, 大小の動静脈病変をきたす血管 Behçet, 脳幹, 小脳, 大脳白質の病変を主体とする神 経 Behçet $の 3$ 型を定義している゙2.

一般的に血管 Behçet は Behçet 病全体の10〜20\% といわれ，多発性で大小あらゆる動静脈を侵す。なか でも動脈瘤は手術をしても再発の危険が高く, 動脈瘤 の破裂は主な死因の 1 つである゙).また, 外科的治療に 


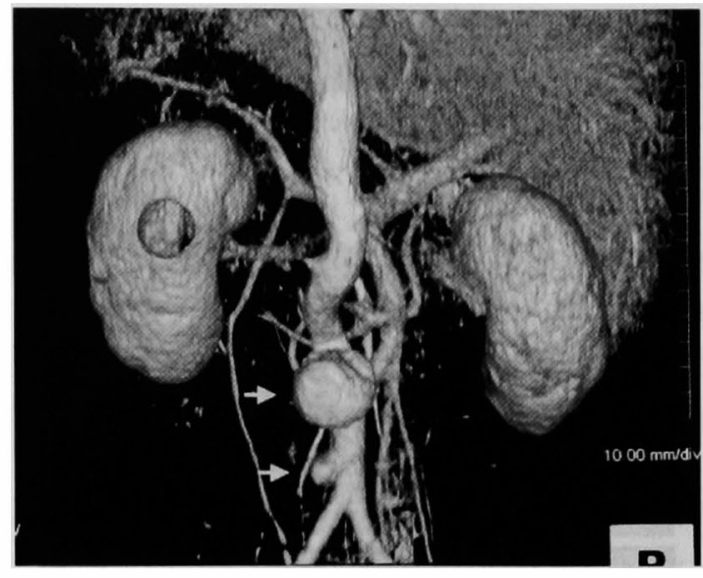

図 3 3D-CT 検査：腎動脈下腹部大動脈に大小 2 力所 の藮状の㔖出を認める (矢印).

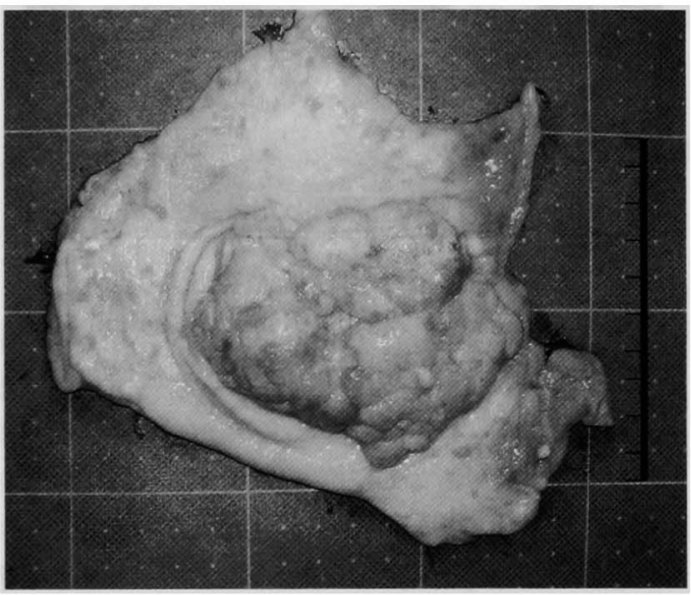

図4切除標本：胃体下部から前庭部にかけて $8 \times 6.5$ $\mathrm{cm}$ の Borrmann 2 型進行胃癌であった.

おいて最大の問題点は吻合部動脈瘤である4). 小池ら の文献的考察によると $22.5 \%$ 発生率があったという が, 実際の発生率はもっと高率であろうと述べている. 本症例は腹部大動脈の腎動脈下に発生した直径約 5 $\mathrm{cm}$ の動脈溜であり, 不整形, 襄状を呈しており, 血管 Behçet としては典型的である.しかし, Behçet 病と消 化管覀性腫瘍の合併は極めて稀で，本邦では胃癌との 合併が本症例を含めて 7 例であり，食道癌が 1 例，大 腸癌が 4 例のみであっだ)-16). 血管 Behçetによる動 脈瘤に消化管癌を合併した症例の報告は，医学中央雑 誌（1983〜2005）でわれわれが調べたかぎりでは，本 邦初である.

膠原病における悪性腫煌の発生率は, 多発性筋炎,

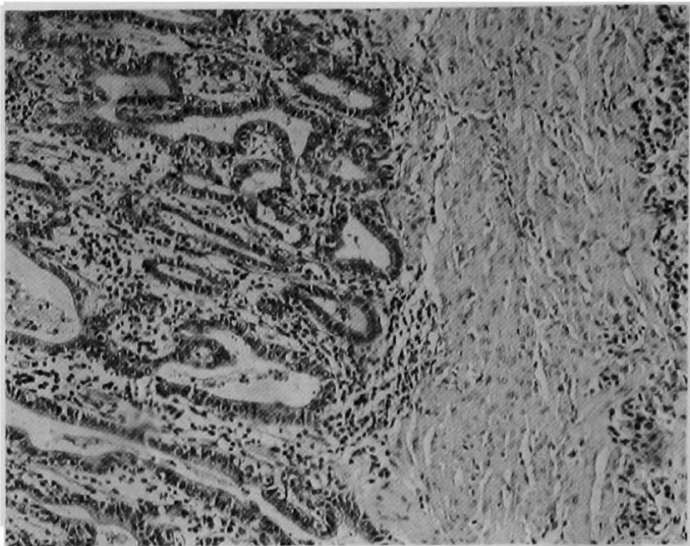

図 5 病理組織検査：中分化型管状腺癌を中心とする腫 瘍細胞が認められる（HE 染色 $\times 200 ） 。$

皮膚筋炎および混合性結合組織病で増加，全身性エリ テマトーデス, 慢性関節リウマチで軽度の増加を示す が, Behçet 病ではそのような報告はない. Behçet 病に 抢ける悪性腫汮の発生は, 多くの場合, 免疫抑制郕の 投与が関係しているといわれているが詳細は不明であ $3^{17)}$.

消化器癌合併腹部大動脈瘤手術は, 一般的に 1 期的 手術は人工血管感染の危険性があるため 2 期的手術が 原則とされてきたが, 直接成績および長期生存率で差 を認めず，可能な症例では 1 期的手術も考慮すべきで あるとされている。しかし，1期的手術の禁忌として は, 全身状態不良で耐術困難な症例, 動脈瘤破裂例, 出血, 閉塞あるいは穿孔を伴った消化管悪性腫瘍症例 があげられ，2期的手術が選択されている ${ }^{181199}$.

現在, 基礎疾患に起因する大動脈瘤に合併した消化 管癌に対する 1 期的手術の報告はない. 今回の症例で は, 前述の血管 Behçetによる動脈瘤における術後合 併症率の高さを考慮し， 2 期的手術を行い良好な術後 経過を得た。今後は個々の症例に応じ，1期的手術か 2 期的手術かを厳重に検討して決定すべきであると思 われた。

$$
\text { おわりに }
$$

極めて稀な Behçet 病に伴う腹部大動脈瘤に合併し た胃癌の症例を経験したため報告した。

本論文の要旨は, 第66回日本臨床外科学会において発表 した.

\section{文献}

1）森山一郎, 木下芳一：腸管ベーチェット病. 臨と 研 $81: 1443-1449,2004$ 
2）広㚼倰成：ベーチェット病. 臨と研 $81: 280-$ 286, 2004

3）岡本宏之, 佐藤 紀：血管ベーチェット. Angiol Front $3: 209-213,2004$

4) Tuzun $H$, Besirli $K$, Sayin A, et al : Management of aneurysms in Behçet's syndrome : analysis of 24 patients. Surgery $121: 150-160,1997$

5）小池茂文, 松本興治, 小久保光治他：Behçet 病の 合併した腹部大動脈瘠術後に発生した大動脈十二 指腸瘦の 1 例と本邦報告95例の Behçet 病動脈瘤 について。 日外会誌 $89: 945-950,1988$

6）赤城一郎, 宮下正夫, 野村 務他：Behçet 病の寛 解期に併存した食道扁平上皮癌の 1 例. 日臨外会 誌 65 (増刊号)：483，2004

7）朝险正宏, 梅北信孝, 真栄城剛他：ベーチェット 病に合併した直腸癌の 1 例. 日臨外会誌 61 (增 刊号) : 467, 2000

8）村上 望, 平野 誠, 宇野雄祐他：Behçet 病に合 併した早期胃癌の 1 例。日臨外会誌 $61 ： 102-$ 105,2000

9）石橋由朗, 小林克敏, 向井英晴他：ベーチェット 病に合併した胃癌の 1 例. 日消外会誌 $31: 1651$, 1998

10）高橋優宏, 高橋正純, 千葉泰彦他：ベーチェット 病に合併して術後残胃穿孔をおこした胃癌の 1 例. 神奈川医会誌 $24: 68-69,1997$

11）藤田繁雄, 高尾哲人, 波辺洋敏他：胃癌を合併し
た腸管ベーチェットに対する 1 切除例. 日臨外会 誌 54 (增刊号)：391，1993

12）大根田絹子, 野村 宏, 沖田 直他：胃癌の硬膜 転移とDICによる硬膜下血腫を認めた神経べー チェット病の 1 例. 臨神経 $30: 333 ， 1990$

13）青井克行, 小山 徹, 石部陽二他：内視鏡的ポリ ープ切除術を行ったベーチェット病患者にみられ た早期直腸癌に 1 例. 広島医 $43: 992-995,1990$

14）鎌田 徹, 山口明夫, 伏田幸夫他：S 状結腸癌手術 直後に腸型 Behçet 病を併発した 1 例. 日消外会 誌 $21: 2331-2334,1988$

15）井上修一, 荒川弘道, 井上義郎地：IIc 様進行胃癌 を合併した Behçet 病の 1例. Prog of Dig Endosc 消内視鏡の進歩 $23: 209-212,1983$

16）下河辺正行, 緒方秀章, 犬丸雅比古地：Behçet 病 に大腸癌を合併した 1 例. 日消病会誌 $80 ： 938$, 1983

17) Cengiz $M$, Altundag $M K$. Zorlu $A F$, et al: Malignancy in Behçet's Disease: A Report of 13 Case and a Review of the Literature. Clin Rheumatol $20: 239-244,2001$

18）松本拓也, 古森公浩, 小野原俊博他：消化器癌合 併腹部大動脈瘤手術症例の検討. 日血管外会誌 $10: 75-80,2001$

19）江里健博，竹中博昭：腹部大動脈㿔と併存する消 化管要性腫瘍 一期的同時手術. 外科 $58: 1867$ $-1869,1996$

\title{
A CASE OF TWO-STAGED OPERATION IN A PATIENT WITH ABDOMINAL ANEURISI COMPLICATED WITH BEHÇET DISEASE AND COEXISTENT GASTRIC CANCER
}

\author{
Hiroyuki NAKAMOTO, Toshiyuki MINOURA, Michio ODA and Atsushi IMAMURA* \\ Department of Surgery, Rakusai New town Hospital, Kansai Medical University \\ *Department of Surgery, Kansai Medical University
}

A 51-year-old male patient who had been treated for Behçet disease since the age of 30 , was found to have a gastric cancer, gross type 2, by endoscopic examination of upper gastrointestinal tract in Aug., 2003. In addition, he was diagnosed to have an infrarenal abdominal aneurysm by CT study. Abdominal aneurysmectomy with graft replacement was performed on Sept. 26th and gastrectomy on Oct. 10th. The postoperative course was generally uneventful and the patient was discharged on the 40th day of operation. However, the patien died 13 month later with appearance of multiple bone metastasis and cerebral hemorrhage due to DIC. This was a typical case of vascular Behçet disease, however, the combination of gastrointestinal tract malignancy is rare. Only 12 cases including ours have been reported in Japan so far. A staged operation was successful in this case, but a careful consideration should be made whether the operation should be staged or not. 